\title{
Re-imagining the role of technology in higher education: the new normal and learners' likes
}

Katharina Greve, Aaron Tan

University of Greenwich, UK

\begin{abstract}
The COVID-19 pandemic forced universities to look at teaching provision. As a result, new technologies, an increasing usage of existing online platforms and alternative ways to engage with learners in the classroom, have together become 'the new normal'. This research aims to answer the questions: how do higher education learners perceive the new role of technology in the classroom? Is technology overload counteracting the potential benefits that blended delivery can offer? In-depth semi-structured interviews with eight students from two seminar groups reveal their positive perception of and continuous interest in the use of technology in the physical and virtual classroom. The study provides examples and recommendations, enabling the effective deployment of technology focusing on three areas: the learner, the facilitator and the technology. Finally, this study makes important contributions to constructivism in the context of technology usage and current and postpandemic pedagogic practice.
\end{abstract}

Keywords: Pedagogy, blended learning, constructivism, edutainment, technology

\section{Introduction}

The COVID-19 pandemic has confronted universities all over the world with unprecedented challenges. Higher education (HE) providers were forced to look at teaching provision and, within a matter of weeks, transformed the delivery of their courses. In October $2020,90 \%$ of United Kingdom (UK) universities started to offer blended learning and $1.3 \%$ of HE providers moved their delivery completely online (Studentcrowd, 2020). Institutions such as

Manchester Metropolitan University (MMU), the University of Manchester (UM), Newcastle and Northumbria Universities even changed their delivery mode after the start of term, owing to increasing numbers of coronavirus infections among the student population (BBC, 2020; McKie, 2020). Following new government guidance, and as of February 2021 , about $92 \%$ of UK universities now offer online learning and only $6 \%$ deliver blended learning (Studentcrowd, 2021). As a result of this development, technology has become an integral part in daily teaching practices. Studies suggest that technologies can help achieving better learning outcomes, a more effective assessment of these outcomes and a more costefficient approach to bringing the learning environment to the learners (Jung, 2003; Shi et al., 2020). The application of technologies, often complementing conventional classroom delivery, has not been a recent development (Papert, 1973). Indeed, the blended-learning approach and the associated benefits are widely discussed in existing literature (GonzalezGomez et al., 2016; Pellas and Kazandis, 2015). However, these technologies have become significantly more important in recent months. In addition to the transformation of teaching and learning by more extensive use of technology, physical classroom layouts underwent 
change, adapted to meet government and university social distancing policies. Because everyone in a classroom is physically separated from all the others, fostering relationships and building trusted connections between staff and learners and between peers have become more difficult.

As effective learning is "inherently a social activity", social distancing rules and online teaching affect the way students learn (Fry et al., 2008, p. 94). The constructivist approach suggests that learners construct meaning and knowledge from experiences, mental structures and beliefs that they use to interpret objects and events. Meaningful learning, as understood by constructivist theory, also emphasises the collaborative role of 'others' in this process. In particular, active interaction with other learners and the instructor plays a role in this context (Bangert, 2004; Partlow and Gibbs, 2003; Rovai, 2004). Indeed, research overwhelmingly supports collaborative learning as the most effective way of learning (Johnson et al., 1984). Learners may compare their version of the truth with that of fellow learners to create a new, socially-tested version of truth. Therefore, the quality of active and engaged interaction is a key determinant of the degree to which 'deep' or 'higher-order learning' is enabled (Bloom, 1956).

Technology that supports social and experiential construction of knowledge is considered effective e-learning (Fry et al., 2008; Vygotsky, 1978). The rise of new technologies, the more widespread accessing of existing online platforms and alternative ways of engaging with learners in the classroom, have become 'the new normal'. What might have been an exciting new approach to enhance learning and engagement in the classroom has, from force of circumstances, transformed and replaced 'live' interaction - the conventional group work and discussions that students were used to. Furthermore, based on the law of diminishing marginal returns (Parkin, 1998), research highlights that relying heavily on technology, once exceeding the optimum level, may actually incur negative outcomes (a curvilinear relationship). Karr-Wisniewski and Lu (2010) describe this phenomenon as 'technology overload'. This begs the question whether constructivist approaches to modelling the learning process are supported or hindered by the increasing deployment of technology in the classroom.

Considering the technology-usage transformation of the HE sector as a result of the COVID19 pandemic, this study investigates how learners perceive the regular use of technology to facilitate interaction in the classroom. This research thus aims to answer the following research questions: How do HE learners perceive the new role of technology in the physical and virtual classroom? Is technology overload counteracting the potential benefits that blended delivery can offer?

Following this introduction, the next section of this article discusses existing literature on the perception of the use of technology in $\mathrm{HE}$, as well as the application of various technologies within the classroom. The third section describes the study's context and the methods that were employed to answer the research questions. The findings and discussion of this study are presented in section four, drawing attention to the critical roles of the learner, the facilitator and the technology. To conclude, the theoretical and practical contributions as well as limitations of this study are discussed. Finally, building on the insights derived in this study, future research directions are outlined. 


\section{Literature review}

\subsection{The perception of the use of technology in higher education}

The COVID-19 pandemic has accelerated the development and adoption of new technologies in HE. In light of this trend, it is important to understand the role of technology and how it can be effectively utilised in the classroom (Müller and Wulf, 2020). Given learners' increased daily exposure to technology, we think it essential to examine how they perceive the now ubiquitous presence of technology-based practice in the classroom.

Some studies argue that the ways in which learners use technologies in their day-to-day interactions with family and friends may often be different from their preferences for technology use in formal learning settings. For example, one study reports that many students stated they preferred technology to "remain within the scope of their private lives" and did not want "technology to eclipse valuable face-to-face interaction with instructors" (Salaway et al., 2007, p.13). A more recent study by Tugun and colleagues (2020) highlights a more favourable perception of the use of technology in HE. This study includes seventyfive mature male and female students from four higher education institutes in Russia. The results reveal that students overwhelmingly supported the use of technology in education leaving them "motivated by the lesson" (Tugun et al., op.cit., p.9). The technological tools provide a medium for effective learning, which is explained in the study as the transfer of "knowledge to cognitive memory" (Tugun et al., op.cit., p.11). A study by Lee et al. (2019) focused on student teachers instead and examined their perception of the use of technology. Student teachers are playing dual roles of learning and teaching as part of their training, providing an intermediary perspective of the topic. Like the findings of Tugun et al. (op.cit.), this research highlights that study participants have a positive view of the role of technology. The student teachers believe it plays an important role in the development of the country, both currently and in the future. These insights from New Zealand are consistent with similar studies conducted in the Netherlands (de Klerk Wolters 1989), Germany, Turkey and Malta (Sjøberg and Schreiner, 2010).

The work by Lee et al. (op.cit.) also shows a noticeable difference between the perceptions of student teachers below the age of twenty-five and those of student teachers aged twentyfive or over. Surprisingly, the latter group expressed more favourable attitudes towards technology in education. Whilst it is unknown exactly why this was the case, it is hypothesised that, because curriculum involving technology was introduced in New Zealand as early as 1995, education authorities there have succeeded in generating positive attitudes towards technology earlier than elsewhere in the world (Lee et al., op.cit.). To understand better the role technology can play in $\mathrm{HE}$ from now on, there is significant value in establishing why there is a meaningful distinction between the respective perceptions of those two different age groups. Oblinger and Oblinger (2005) highlight a generational aspect in relation to students' use of technologies. The authors describe the characteristics of the 'net generation', which includes students born after 1980. They suggest that these students differ profoundly from previous generations in the way they process information, communicate and hence learn. They claim that the 'net generation' is comfortable with technologies and the scholars argue that the ways in which members of this group learn is task-orientated and experiential. The study points out that learners prefer to receive information quickly, are used to processing information and multi-tasking and employ multiple/multi-modal communication channels to access information and communicate with 
peers and tutors (Oblinger and Oblinger, op.cit). A more recent study by Hernandez-de-Menendez and colleagues (2020) discusses the educational experiences of Generation Z, which includes individuals born after 1995. This generation is "born with technology"; they are considered digital natives (p.849). As a product of their close attachment to technology, they are also known as 'iGeneration', 'Gen Tech', 'Online Generation', 'Facebook Generation' and 'Switchers' and they are "always clicking” (Dolot, 2018; Hernandez-de-Menendez et al., 2020). Researchers suggest that educators should incorporate technology in the teaching-learning process in a creative way. For example, podcasts, websites, simulations, interactive YouTube tutorials and internet-based educational games are some of the technologies that can help to capture the attention of Generation Z, while social media like Twitter and Tumblr can be employed for communication and sharing of knowledge. Facebook is described as a useful tool for discussions or posting updates about class activities (Eckleberry-Hunt et al., 2018). In order to educate Generation Z with technology effectively, Tolbert (2015) describes six assumptions, summarised in table 1 , that should be considered.

Table 1. Assumptions of technology

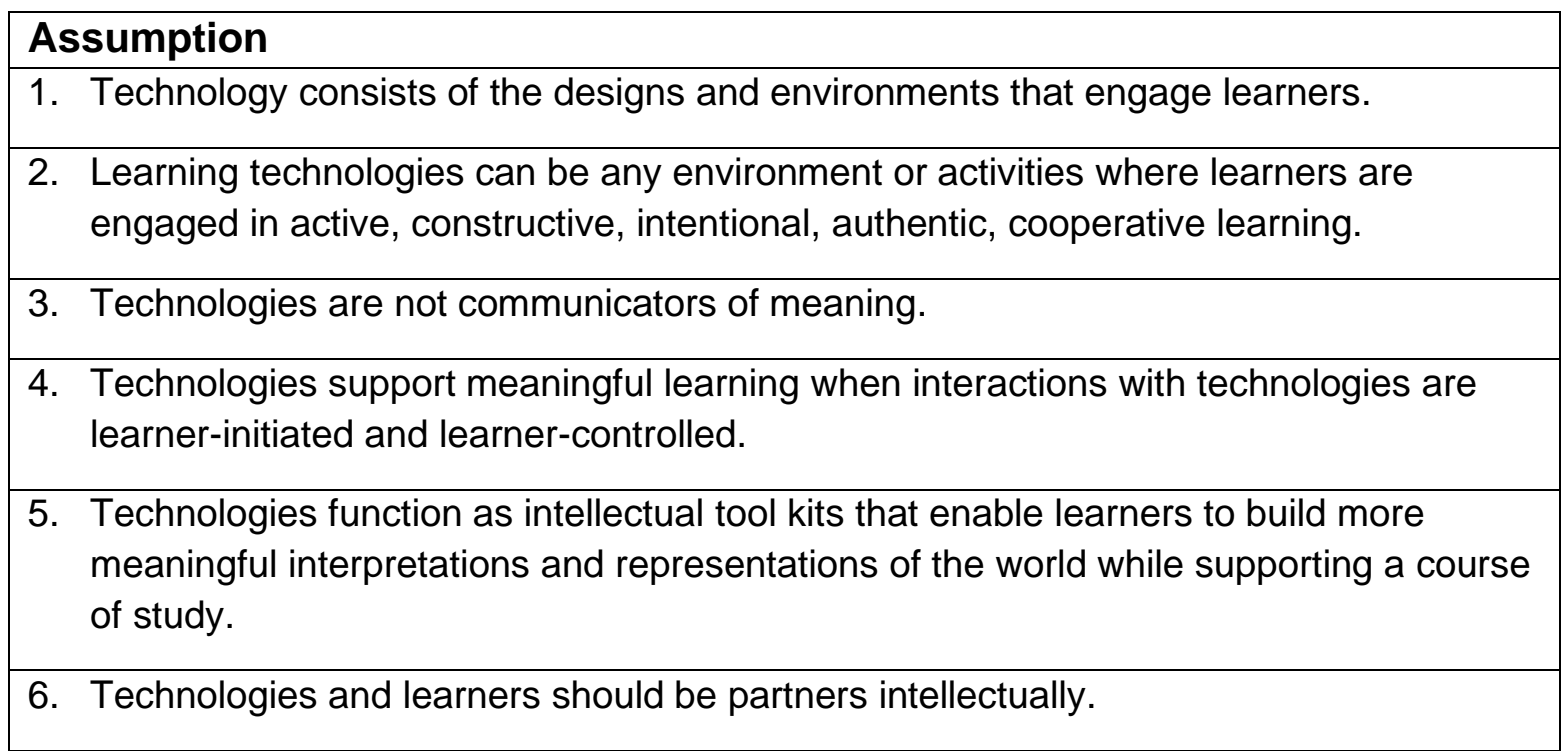

Source Tolbert (2015)

Aside from generational differences, studies also investigate the perception and use of technology in relation to different disciplines. For example, Kirkwood and Price (2005) relied on Open University data spanning five years to examine students' attitudes to and experiences of technologies. The study reveals a dramatic increase in students' access to and use of information and communication technology (ICT) over the five-year period. Their meta-analysis shows that there were differences in students' experience of and attitude towards technologies across subject disciplines. A study by Lam et al. (2014) finds that although students of different disciplines did not vary a great deal in their everyday usage of technology, there were variations in their level of confidence in using it. The scholars report that the use of technology differs across disciplines, though "all students have a similar (and positive) view about the need for the use of technology for teaching and learning" (Lam et al. (2014, p.11). 


\subsection{The deployment of different technologies in the classroom}

Overall, the number of studies exploring the use and usefulness of technologies in HE is growing (Henderson et al., 2015). Yet, the much-discussed potential of 'technologyenhanced learning' is not always apparent, often lacking clarity because of varying definitions, uses and understanding of the term 'technology'. For example, Tugun et al. (2020) refer to computers as technological tools used for education. However, computers incorporate a variety of functions and applications - including, but not limited to, a calculator, media player, word processor and graphic design tools. Thus, treating computers as a synonym for technology ignores its various functions and tools and how these are being utilised. As a result, the true extent to which computers are used for educational purposes is not clear. In addition to the inconsistent and unclear use of the term, some studies (Jack and Higgins, 2018) also highlight that the areas and activities in which technologies are being deployed are not always evident. A review of existing literature by Jack and Higgins (2018), on how technology is used in education, reveals that there is a large focus on computers and tablets, these being mentioned in close to seventy-five per cent of the reviewed journal articles. The scholars point out that "it was unclear how technology was being used" (p.224). Lim (2002) supports this statement by identifying that "... many [studies] lack detailed investigation of what takes place in the ICT learning environment" (p.411).

A recent survey reports that British university students spend an average of fifty-five hours per week online, only fourteen hours of which are dedicated to their studies (Hughes, 2019). This further exemplifies that, whilst technology may be received favourably overall, the specific application or use of the term 'technology' in the context of HE needs to be refined. The value of doing so is raised given the tendency of universities to introduce new pedagogical approaches using technological tools as a consequence of changing social demands (Justice et al., 2009). Using terminology with precision would allow for a more focused analysis and subsequent interpretation of such studies. Establishing a baseline "understanding of technology [...] enables the establishment of clear goals, classroom activities and authentic contexts" (Lee et al., 2019. p.439).

A growing trend incorporating technology is the application of digital games-based learning and gamification in HE. Advance HE (2021) defines digital games-based learning as "the integration of gaming into learning experiences to increase engagement and motivation" and "gamification refers to the use of a pedagogical system that was developed within gaming design but which is implemented within a non-game context'. This trend reflects students' engagement with technologies. As Tugun et al. (2020) point out, the second most common use of technology by mature students at university is playing games. In line with this observation, the concept of 'edutainment' evolved. It combines elements of entertainment and education as an attempt to attract the attention of the learner and maintain engagement. The concept is largely overlooked in educational practices (Aksakal, 2015). There are several approaches to implementing practices linked to edutainment which are summarised in table 2. 
Table 2: Approaches to edutainment

\begin{tabular}{|l|l|}
\hline Description & Outline \\
\hline $\begin{array}{l}\text { Taking a role in } \\
\text { interaction }\end{array}$ & $\begin{array}{l}\text { Activities such as class discussions and debates allow students } \\
\text { to participate, situations in which their active roles are integral to } \\
\text { the learning experience. }\end{array}$ \\
\hline Dramatisation & $\begin{array}{l}\text { The use of role play or performance allows students to reflect on } \\
\text { how they would react to given scenarios. }\end{array}$ \\
\hline Story (simulation) & $\begin{array}{l}\text { Treating events as if they were real and then using the outcomes } \\
\text { as the basis of reflection. }\end{array}$ \\
\hline $\begin{array}{l}\text { Curating a positive } \\
\text { classroom } \\
\text { atmosphere }\end{array}$ & $\begin{array}{l}\text { The teacher addresses the physiological and physical } \\
\text { environment of the classroom setting. }\end{array}$ \\
\hline Using computers & $\begin{array}{l}\text { Using computers to attract and retain the attention of students } \\
\text { with the use of colours, animations and interactivity. }\end{array}$ \\
\hline Use of TV programs & $\begin{array}{l}\text { Documentaries featured on channels such as 'The Discovery } \\
\text { Channel' and 'The National Geographic Channel'. }\end{array}$ \\
\hline
\end{tabular}

Source: Adapted from Aksakal (2015)

Interactivity through the use of computers is one approach to edutainment. More specifically, interactive platforms such as Mentimeter can be utilised to create attract and retain students' attention. Growing numbers of studies, reviews and blogs discuss the application and effectiveness of the platform. For example, a study by Mayhew (2020) reveals that $96 \%$ of students had a positive experience using Mentimeter and $82 \%$ of study participants felt more satisfied with teaching sessions that used the platform compared to those that did not. The study further highlights that $68 \%$ of participants experienced an increase in their learning levels, which suggests that Mentimeter helps to facilitate effective learning. There are additional benefits associated with Mentimeter, such as enhancement of the student voice because users preserve anonymity; greater peer-to-peer interaction and a way for teachers to make more use of formative assessments to monitor the understanding of the cohort. At the same time, Mayhew (2020) points out that the effective use of Mentimeter (in a live setting) is dependent on the skills of the lecturer and her/his ability to encourage participation, respond to answers and manage the noise resulting from the excitement it generates. Studies focusing on similar platforms, such as Padlet and Zapworks, also report positive results: Padlet was received favourably by $100 \%$ of dentistry students and $80 \%$ of biomedicine students (Mehta et al. 2021); Zapworks was seen by $80 \%$ of students as helpful in understanding the material covered in lectures (Reeves et al. 2021).

One of the more common uses of technology in HE relates to the recording of lectures. Ebbert and Dutke (2020) conducted a study examining students' usage of recorded lecture material. The scholars identify that students have varying usage patterns for the recorded lectures, depending on their own goals. For example, Gorissen et al. (2012) recognise that students may watch entire recordings of lectures to supplement their understanding; some students watch specific parts of the lecture recordings to gain clarity on a particular topic while others watch the lecture recordings in preference to attending the live lectures. Studies suggest that lecture recording enables deeper engagement with course material (Zhu and Bergom, 2010) and that students learn better as it allows pausing and resuming the lecture when desired (Dey et al., 2009). Lecture recordings are considered beneficial because they 
help in clarifying concepts discussed in class and are convenient for the review of material (Toppin, 2011). Research has shown that students who are non-native English speakers, or have learning adjustments, use the learning recordings much more (Nordmann and Mcgeorge, 2018).

Whilst technology has clear benefits and advocates, it is important to investigate the limit to which these benefits materialise in the current circumstances. Karr-Wisniewski and Lu (2010) explore the potential of technology overload, which can lead to diminishing returns: ultimately, the introduction of more technology can cause negative outcomes and result in a curvilinear relationship. Studies (Fuglseth and Sørebø, 2014) have found that when users experience anxiety and tension caused by over-using technology, they develop such a disposition towards technology as may cause nervousness and apprehension in using it. As a consequence, it has negative effects on users' satisfaction and performance (Tarafdar et al., 2010). Delpechitre et al. (2019) explore technology overload in a workplace setting and conclude that technology overload can increase stress and lead to a decrease in the level of performance. One of the implications drawn from the study was that managers should consider carefully when improvements in technology are introduced. This would help to reduce the stress of employees having constantly to learn and adapt to new technologies alongside their day-to-day activities. The pandemic and the sudden, almost contemporaneous switch to a blended-learning approach illustrated how students may experience heightened stress levels if new technologies and new teaching practices are introduced simultaneously, even if they are measures intended to allow students to continue with their education. The use of communication technologies, such as Zoom, MS Teams or Webex, re-designed virtual learning environments and engagement through different interactive tools suddenly became the new normal. Harris et al. (2015) identify three types of technology overload. First, the scholars highlight 'information overload', which occurs when more information is provided than an individual can cognitively process. Second, 'communication overload' is recognised. This takes place when an individual is interrupted excessively by, for example, email, instant messaging or mobile devices. Third, the authors identify 'system feature overload', when the technology provided is too complex for the task at hand (Harris et al., 2015). While studies define and measure technology overload differently (Karr-Wisniewski and Lu, 2010; Tarafdar et al., 2010; Choi and Lim, 2016; Harris et al., 2013; Harris and Marett, 2009), the underlying concerns are of similar nature. More recently, the COVID-inspired phrase 'zoom fatigue' has gained attention in the media (Harvard Business Review, 2020; Bradshaw, 2021), describing "tiredness, worry, or burnout associated with overusing virtual platforms of communication" (Lee, 2020). Considering the daily exposure to and usage of different technologies and the potential negative implications that technology overload can cause, it is critical to understand students' perception of the use of technology in the classroom.

\section{Methodology}

\subsection{Research Context}

To explore students' views on the use of technology in the physical and virtual classroom, undergraduate students from two seminar groups were interviewed. Students experienced a range of different technologies in their online tutorials as well as during face-to-face teaching on campus. In line with governmental and university-specific social distancing rules, each seminar group experienced one week of on-campus teaching without technology support 
and one week on-campus teaching employing a number of different technologies to facilitate interaction in the classroom.

The first seminar included two activities. First, students were asked to reflect on and respond to three open ended questions related to entrepreneurship. Second, students were asked to discuss and rank in order of importance a number of skills/traits of entrepreneurs. One seminar group carried out these activities without the help of technologies. In the other seminar group, the students - divided into groups and asked to engage with each other online - responded to the questions via MS Google Docs. For the second task, students, using Mentimeter (an interactive presentation software), ranked in order of importance a number of skills/traits of entrepreneurs. For the following - on-campus - seminar, the seminar group that had previously not relied on technology used it and, in a similar reversal, the other seminar group interacted directly, without technology. The same approach was adopted for online tutorials. MS Teams - the hosting platform of the tutorial class - included online sessions that incorporated additional technologies, while others - involving instructorled exercises and discussion - did not. In the context of this study, exposing students to a variety of technologies in some sessions but not in others, where technologies and tools were withheld, allowed learners to experience the difference directly and to reflect upon that. Tutors, meanwhile could, observe which technologies students were able to engage with more effectively to achieve the intended learning outcomes. In addition to direct observations of the students using different technologies, tutors also engaged with the tools during the class, allowing them to make participant observations.

Throughout the term, students engaged with a number of different tools and platforms, as summarised in table 3 . Although the module utilised various technologies, this study specifically focuses on students' perceptions of activities that incorporated Mentimeter, Google docs, High Fidelity, YouTube and Panopto. Other technologies and platforms are listed to provide contextual information about students' engagement with technologies that play a role in the delivery of the module.

Table 3: Application and role of technologies

\begin{tabular}{|l|l|l|l|}
\hline Technology & Description of key features & $\begin{array}{l}\text { Application in } \\
\text { class }\end{array}$ & $\begin{array}{l}\text { Role in this } \\
\text { study }\end{array}$ \\
\hline Mentimeter & $\begin{array}{l}\text { Mentimeter is an interactive } \\
\text { presentation platform with features } \\
\text { that enable the user to prepare, } \\
\text { present and analyse presentations. }\end{array}$ & $\begin{array}{l}\text { - Quiz } \\
\text { - Poll } \\
\text { - Ranking }\end{array}$ & Focus \\
\hline Google docs & $\begin{array}{l}\text { Google Docs enables individuals to } \\
\text { collaborate to write reports, create } \\
\text { joint project proposals, keep track } \\
\text { of meeting notes and do various } \\
\text { other things. }\end{array}$ & $\begin{array}{l}\text { - Group work via } \\
\text { shared Google } \\
\text { Doc }\end{array}$ & Focus \\
\hline High Fidelity & $\begin{array}{l}\text { High Fidelity provides a virtual } \\
\text { reality platform for users to join } \\
\text { together to create, deploy, visit, } \\
\text { and interact with virtual worlds. }\end{array}$ & $\begin{array}{l}\text { - Discussion-based } \\
\text { task }\end{array}$ & Focus \\
\hline
\end{tabular}




\begin{tabular}{|c|c|c|c|}
\hline YouTube & $\begin{array}{l}\text { YouTube is an online video-sharing } \\
\text { platform. It allows users to upload, } \\
\text { view, rate, share, add to playlists, } \\
\text { report, comment on videos, and } \\
\text { subscribe to other users. }\end{array}$ & $\begin{array}{l}\text { - Presentation of } \\
\text { information about } \\
\text { case studies }\end{array}$ & Focus \\
\hline Panopto & $\begin{array}{l}\text { Panopto is a video platform which } \\
\text { enables users to create and share } \\
\text { videos securely. }\end{array}$ & - Lecture recordings & Focus \\
\hline $\begin{array}{l}\text { Microsoft } \\
\text { Teams }\end{array}$ & $\begin{array}{l}\text { Microsoft Teams is a collaborative } \\
\text { workspace that acts as a central } \\
\text { hub for team collaboration and } \\
\text { integrates the people, content, and } \\
\text { tools. }\end{array}$ & $\begin{array}{l}\text { - Online tutorials } \\
\text { (video and chat) } \\
\text { - Q\&A after video } \\
\text { presentations for } \\
\text { students abroad }\end{array}$ & Context \\
\hline PowerPoint & $\begin{array}{l}\text { PowerPoint is a presentation } \\
\text { program that allows users to } \\
\text { create, edit, view, present or share } \\
\text { presentations. }\end{array}$ & - Tutorial slides & Context \\
\hline Moodle & $\begin{array}{l}\text { Moodle is a learning platform or } \\
\text { course management system } \\
\text { (CMS). }\end{array}$ & $\begin{array}{l}\text { - Repository of } \\
\text { module resources } \\
\text { (e.g., slides, } \\
\text { videos) }\end{array}$ & Context \\
\hline
\end{tabular}

\subsection{Research Methods}

This article is based on qualitative research - particularly suitable, as little is known about students' perceptions of the use of technology in the context of the COVID-19 pandemic. Qualitative methods play an essential role "[in achieving] understanding of a particular situation, or individuals, or groups of individual, or (sub)cultures, etc., rather than [in explaining and predicting] future behaviours" (Bendassolli, 2013, p.2). Semi-structured interviews are employed with a fairly open framework, in order to encourage focused, conversational and two-way communication (Bernard, 1995). The approach is suitable for this exploratory research, which investigates what is scarce in the research literature: participants' opinions, experiences and knowledge in relation to their perceptions of the use of technology in the classroom in the specific context of the COVID-19 pandemic. Using qualitative data to address the research objective of this study offers insights both rich and explanatory in nature.

Following ethical approval by the University Research Ethics Committee, semi-structured interviews with eight level five students from two seminar groups were conducted. The students study business degrees and are, with the exception of one student of over fifty years of age, between twenty and twenty-four years old. The study is based on intensity sampling, which Patton (1990, p.171) describes as "information-rich cases that manifest the phenomenon of interest intensely, but not extremely". This approach aligns with the objectives of this study and included students who had attended relevant seminars that exposed them to the various technologies as well as sessions in which technology played no 
role. An overview of study participants is provided in table 4. The names of students have been anonymised.

Table 4. Study participants

\begin{tabular}{|l|l|l|l|}
\hline Student & $\begin{array}{l}\text { Male or } \\
\text { female }\end{array}$ & $\begin{array}{l}\text { Tutorial } \\
\text { group }\end{array}$ & Programme of study \\
\hline Amy & F & 1 & BA Hons Logistics and Transport Management \\
\hline Boris & M & 2 & BA Hons Business Entrepreneurship and Innovation \\
\hline Charles & M & 2 & BA Hons Business Entrepreneurship and Innovation \\
\hline Dorothy & F & 2 & BA Hons Logistics and Transport Management \\
\hline Eva & F & 2 & BA Hons Business Entrepreneurship and Innovation \\
\hline Frank & M & 1 & BA Hons Business Entrepreneurship and Innovation \\
\hline Greta & F & 1 & BA Hons Business Entrepreneurship and Innovation \\
\hline Henry & M & 2 & BA Hons Logistics and Transport Management \\
\hline
\end{tabular}

The in-depth interviews lasted between thirty minutes and sixty minutes and included four female and four male study participants. One interview was carried out in person, while the remaining interviews each took place via an MS Teams video call. Following participants' consent, the interviews were recorded and transcribed using intelligent verbatim transcription. The interview data is complemented by the tutors' direct observations and participatory observations. Observations are suitable in the context of this research as they offer opportunities to study non-verbal expression of feelings, assess who interacts with whom, examine how students communicate with each other and investigate how much time is spent on a number of activities and how students navigate different technologies (Schmuck, 1997). Data coding and categorisation in Nvivo were carried out to analyse the data thematically.

\section{Findings and discussion}

Taking into consideration the unique context of the COVID-19 pandemic, this study examines students' perception of the use of technology in the physical and the virtual classroom. For effective employment of technology in the classroom, findings suggest a focus on three key areas (figure 1): the learner; the facilitator; and the technology. In the context of particular classroom activities, and considering the nature of the module and discipline, these areas and their relationship are further explored in the following sections. 
Figure 1: Focus areas

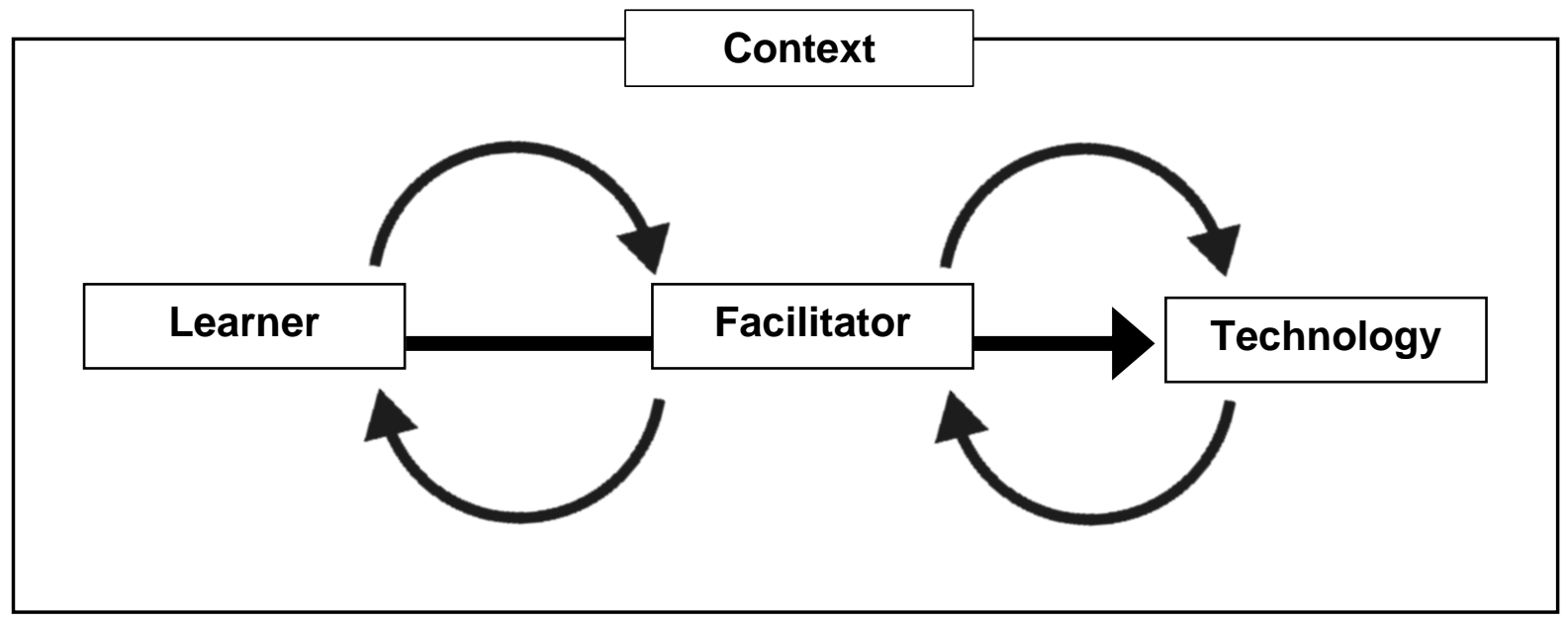

\subsection{The Learner: Leveraging technology skills and gaining confidence}

"Technology is the way forward" - Charles. This student reflects on the role of technology during the pandemic and remarks: "I am not saying the pandemic was a good thing but most of us come to realise that technology is essential'. Despite students' exposure to a variety of technologies as part of their everyday lives, it is important to address the assumption that all learners are comfortable with using technology and assess what their actual abilities are. This is important because "a learner is unable to participate fully in technology if they do not have the understanding and desire to become involved" (Lee et al., 2019, p.449). This is particularly relevant, as COVID-19 has accelerated the digital transformation of HE, exposing learners to new technologies and modes of delivery (World Economic Forum, 2020). Apart from Amy, who rates her IT skills as very low, the interviews reveal that students are largely confident in their basic use of IT. This is not entirely surprising because, as one participant states, "most people at university [...] have a phone or computer" - Boris. As technology is ingrained in everyday life, the transition to using technology for educational purposes is, for many students, merely an extension of existing skill sets rather than needing to acquire new ones. These findings align with other studies (Hernandez-de-Menendez et al., 2020) that describe Generation $Z$ as 'digital natives'. Even the mature student, belonging to Generation X, says he is comfortable using different technologies once he has an opportunity to learn to navigate them. He describes himself as a quick learner and keen to adopt new skills for using technologies he has previously been unfamiliar with: "Once I learn it, I am ready. I am always keen on using it. Since the lockdown, I use it more than probably the past 7 years. It is part of our daily lives now" - Charles.

Today, the application of technology in HE extends beyond projecting visual aids. Instead, technology is increasingly used to create virtual discussion spaces, produce simulations, hold opinion polls, interact in chats, develop digital mind maps, brainstorm ideas on virtual white boards and do many other things with applications and tools. While this provides an exciting opportunity for tutors to add to their toolkit, it is easy to make assumptions as to how competent students are in using technologies that they may not engage with in their daily lives outside the classroom. Indeed, in their comments, students reveal that they are largely unfamiliar with Google Docs and certainly have had no previous experience of Mentimeter and High Fidelity until using them in class. As someone rating her own IT skills as very low 
and being previously unfamiliar with these technologies, Amy says she has benefited from her tutor's guidance: "It was well explained in class".

The challenges that present themselves when students attempt to engage with new technology are exemplified through the case of High Fidelity, a platform used as part of this study to host discussions. Students were given an avatar which they used to navigate around a virtual environment, engaging in discussions with others. Just like discussions in a physical space, the closer the avatar was positioned in the virtual environment to those of other students, the better they could hear each other. Though the students described themselves as confident IT users, they found this platform "awkward" and difficult to use. Eva's comment illustrates this: "the [platform] itself has technical difficulties". Indeed, it is worth noting that this platform has not reached full maturity as its development halted in early 2020. Students' responses suggest that, to employ the technology effectively, a prior orientation session as part of the curriculum may be beneficial. Furthermore, interviewees explain that learning new technologies is something they enjoy and consider beneficial. Charles states that "it is better we learn it [tools] now, so that we can master it in whatever business we will need it in the future".

Figure 2: Summary: The Learner

The tutors' observations and the insights delivered through interviews with students reveal that deploying technologies in the classroom effectively requires:

- assessing learners' level of IT literacy;

- examining learners' experience with particular technologies;

- providing training and supporting to learners navigating different technologies.

\subsection{The Facilitator: Integrating technology in teaching and learning practices}

This study identifies the critical role of the facilitator in relation to the effective use of technology in the classroom. Frank comments on the role of the tutors: "The way [the tutor] engages the class is a good thing which makes tasks easier." In one tutorial, students have watched short YouTube videos that explain the failure of three well-known businesses in adapting their operations to local cultures. Though the students describe their tutors as skilled and engaging, they express a preference for technology to address this particular task. When asked if students could choose between watching these video clips and listening to the tutors' own case summaries, Charles is diplomatic, but clearly prefers the videos. He points out that "we can't remove the tutors, they are doing a perfect job, don't get me wrong [...] but what I am saying is that the combination of the tutors, showing the videos to us and then giving us their take on it provides the best out of both worlds". Eva has little doubt: "I'd prefer to watch the videos to get my own understanding of [the case studies]". It was evident that students preferred watching YouTube videos to receiving a case summary from the tutor, however, this does not imply that students would like to replace direct interaction with tutors. Instead, learners emphasise the complementary role that technology should play, with its capacity to enhance some classroom activities. In this situation, the video clips helped students to gain a deeper understanding of content by means of pictures and video 
sequences. Students also consider technology beneficial if employed in combination with class discussions. Tools such as Mentimeter were found to be particularly useful when polls of opinions could be taken and the results then explored further through tutor-led discussions. The rationale provided by the participants is that "technology is practical but misses emotional intelligence" - Boris. Referring to an exercise using a shared Google Doc for group work, Amy explains her preference for combining the use of technology with discussions: "I cannot imagine just writing in google docs my ideas". Charles reflects on some challenges during the exercise: "Initially, we were all in the chat room as we could not directly communicate with each other. Then someone took charge [regarding the task] and we followed his lead. I have not used this aspect of the technology before but it was a learning process for me." Amy explains that being able to compare her understanding to that of other students, on the basis of how peers react during classes, forms a part of her learning. This substantiates the perspective that learning is "inherently a social activity" (Fry et al., 2008, p.94) and ties in with elements of common social learning theory and constructivism. Indeed, Bandura's (1977) social learning theory argues that we learn by observing and modelling the behaviour of others. This theory has been pivotal in understanding how we learn and, therefore, findings from this study suggest that to leverage technologies that enhance social learning establishes a suitable environment for learning to occur.

Boris describes his experience of technology in education: "like gravy: its good without it but better with it". This analogy further illustrates the complementary role of technology, about which all study participants are in agreement. Learners' views concerning the extent to which technology is used in an educational setting is divided. One participant offers, as a rule of thumb, having teaching sessions with $30 \%$ technology and $70 \%$ without. Henry suggests $60 \%$ of tutorial time without technology and $40 \%$ supported by it. He prefers to spend more time interacting without technology because it leads to a "better flow of discussion and better ideas". Dorothy also states that, during lessons taught in the physical classroom, she would "prefer less technology and prefer more face-to-face engagement". Charles, Dorothy, Frank, and Greta agree. However, none of the learners would want to abstain from technologies during on-campus sessions; they just want more direct interaction than interaction through technology. Overall, students are positive about the current use of technology in a blendedlearning environment. Charles specifies his position regarding virtual interactions and highlights that, while students were off campus, MS Teams "was convenient and easier as we could deal with issues quickly". Despite their differing views on the extent to which technology should be deployed, the consensus among the participants is that the majority of time spent in tutorials should be focused on interaction with others, with technology playing a supportive rather than dominant role in the learning activities. "With Google [Docs] all we did was write down notes, we didn't really discuss" - Eva. She suggests that "it is best to use a combination of technology alongside [face-to-face] communication". Students' preference for a blended approach also aligns with research findings by Means et al. (2013) who use metaanalysis of the empirical literature, taking into account forty-five studies. The scholars conclude that "blended approaches have been more effective than instruction offered entirely in face-to-face mode" (p. 35).

In line with the blended-learning approach, the role of the facilitator is to integrate technologies effectively with traditional instructor-led classroom activities, giving students more flexibility to customise their learning experiences. Students appreciate engaging with a 
variety of technologies, as to do so makes the classroom activities more interesting. Finally, this study finds that students appreciate instructors' trying out new technologies even if the desired outcome is not achieved. "Even when you are failing, it is not really a fail because [...] next time we learn from those mistakes" - Amy.

Figure 2: Summary: The Facilitator

The tutors' observations and the insights delivered through interviews with students reveal that deploying technologies in the classroom effectively requires:

- possessing skills and competencies as a facilitator to navigate different technologies;

- integrating technologies as a supportive tool, complementing instructor-led activities;

- being open to trying new tools.

\subsection{The Technology: Recognising the nature and context of the tool}

This study recognises that employing technology in the classroom effectively is linked to the type of technology and the context in which it is utilised. For example, tutors' observations during the sessions using High Fidelity highlight a number of conditions vital to enabling the successful deployment of this particular technology. First of all, students have to be in a quiet learning environment, as all learners on the platform are simultaneously unmuted. The class size has therefore to be relatively small, so that everyone is able to engage in discussions without interruptions. At the same time, students have to have a stable internet connection and sufficient audio quality. Boris explains that it "was difficult; we could not hear a voice clearly". Similarly, Dorothy reflects: "I could not understand why I could not attend it [high-fidelity], nobody could hear my voice. Maybe it was my fault and not the app".

According to Harris et al. (2015), technology that is too complex can cause 'system feature overload'. Boris continues to suggest that social dynamics play a role and, for learners to interact with each other, it might be more beneficial if the tutor assigns a couple of students to breakout rooms instead of deploying High Fidelity. In line with these findings, other studies (Smyth et al., 2012) report that having difficulties with more sophisticated technologies represents a challenge to successful implementation of blended learning. In particular, reference is made to students' having slow internet connections (Smyth et al., 2012) which prevents students from engaging in online discussion (King, 2002) and causes frustration (Hara, 2000; Hara and Kling, 1999). Considering these pre-requisites and the barrier for students to engage effectively in discussions on account of the complexity of the platform and social dynamics of larger groups, the nature of the technology and its functions have to be taken into consideration.

'Fun' is the word repeated frequently to describe technologies that were perceived positively. Study participants state that employing different technologies makes classroom activities more fun and diversified. Findings align with advocates of game-based learning (Prensky, 2007) who suggest that students require learning to be fun and entertaining. Gamification in education and how it can be used to engage students more consistently is also a theme reflected in the study by Tugun et al. (2020). The scholars reveal that the second most 
common use of technology of university students after communication is for playing games. This could provide a reference point for tutors as to how to include technology to complement their traditional teaching methods. This would avoid the dilemma of having to include technology in lessons for reporting purposes and being seen to 'keep up' at the expense of facilitating effective learning and the transfer of "knowledge to cognitive memory" (Tugun et al., 2020, p.11). Repeatedly mentioned in this context is the tool Mentimenter, which is seen as fun and easy to navigate. This is in contrast to High Fidelity, which is considered difficult and not beneficial for tackling the task at hand.

Indeed, attention should be paid to the nature of the task and anticipated learning outcomes when choosing technologies. For example, a shared Google Doc was utilised for a group task, so that students could work in teams and compile their arguments in a shared file. Dorothy noted that several students did not engage with the task and relied on others to compile the notes in the shared file. Other students recognised the benefits of such a shared resource which can serve not only as a useful resource during class, but also as a shared repository for future use. Dorothy says: "I can now use it for my assignment". One of the main benefits of the blended environment is the students' ability to refresh and revisit material: for example, watching pre-recorded lectures at any time and as many times as needed. During the course of the interviews, Dorothy mentioned that this might be of particular relevance to non-native speakers, as tools such as Panopto offer captions, which aids comprehension. Students point out that a purposeful approach to deploying technology has to be adopted and the benefit of using a particular tool has to be clear.

This study suggests that students have a preference for technologies such as Mentimeter that are considered fun and user-friendly. This could be partly because of the element of gamification that comes with the platform and the context in which it is used. The tool is also seen as useful because it allows students to get a sense what others in the classroom think. Furthermore, both Amy and Dorothy suggest that they remember content better and that their learning is more effective when using Mentimeter in class: "I can see the right and wrong answers afterwards. It is also competitive and sometimes you can see the ranking of people in your class [answering the questions] and it also introduces a little bit of fun as well" - Amy. Greta mentions that "without technology we wouldn't have the correct answers [...] we were able to take photos of it to reflect in the future". Instead, Google Docs is seen as a useful tool for group activities involving note-taking, as the notes can be accessed in the future (e.g. coursework preparation). However, when Google Docs was used as part of wider class discussions, its benefits became much more limited. Eva says that "technology was not needed as it spoils the discussion". This sentiment highlights the importance of resisting the automatic urge to associate technology with positive student perceptions and the importance of deploying technologies purposefully and context-specific. "The use of technology depends on the activity it is being used for" - Greta. The use of different types of technology needs to contribute to or be a logical extension of the planned teaching activities if students are to perceive them positively. Simply using technology for no specific benefit or purpose might well negate the benefits it would otherwise deliver. Finally, the technology should not create any barriers for engagement because of the level of conditions that need to be fulfilled, including - but not limited to - stable internet connection, quiet learning environment and audio quality. 
Figure 2: Summary: The technology

The tutors' observations and the insights delivered through interviews with students reveal that deploying technologies in the classroom effectively requires:

- considering essential requirements to engage with the technology;

- recognising the complexity of the tool;

- selecting the tool with the task and learning outcomes in mind.

\section{Conclusion}

\subsection{Contributions}

In the light of the unprecedented circumstances generated by the COVID-19 pandemic, this study delivers new insights into learners' perception of the effective deployment of various technologies in the physical and virtual classroom. Given the risk of technology overload, the findings expose potential misconceptions about students' willingness to use technology to support their learning. Indeed, despite the increased exposure to and application of technologies in the daily lives of students, this study finds that learners remain interested in engaging with technologies in the classroom. Furthermore, study participants agree that the use of technology has supported their learning.

Rather than using technology as a catch-all term, this study highlights the application of particular tools and platforms and describes the context in which they are deployed. More specifically, this study advances our understanding of the dimensions that need to be considered for effective HE application of particular technologies, contributing important elements to social learning theory and constructivism.

This research also delivers practical insights into the effective use of different tools in the classroom. Based on in-depth interviews with learners and complemented by tutors' observations, this study identifies three areas of importance: the learner; the facilitator; the technology. Findings suggest that the learners' level of IT literacy, together with their previous experience with particular technologies, must be assessed. This is important, so that appropriate tools, aligned with the learners' skills and confidence, are selected. In line with the learners' skills' level, training and support have to be provided to enable the learner to navigate different technologies. The role of educator is also essential, for the skills and competencies in navigating the tool and facilitating the technology-supported activity play a fundamental role. The facilitator should integrate technologies as a supportive tool, complementing instructor-led activities. Furthermore, the educator should remain open to exploring new tools. The technology itself represents a key aspect that requires attention. Essential requirements to engage with the technology, such as stable internet connection and audio quality, need to be considered. The complexity of the tool needs to be recognised and the tool should be selected with the task and learning outcomes in mind. The three areas highlighted in this study should not be seen in isolation but rather as factors that are closely linked, informing one another. 
The analysis has mirrored much of the existing literature focused on technology, especially in a blended-learning context, confirming it as beneficial and effective. However, technology is often used as a broad term for any electronically powered device or as a synonym for the term 'computer', which in itself is arguably a broad term. As stated in the review of the literature, an absence of a definition of the term 'technology' in the HE context or any distinction made between the types of technology employed may prevent educators from fully capitalising on the benefits that different tools have to offer. This may well lead to illinformed teaching practices. This study highlights the importance of differentiating between the technologies that are being deployed in the classroom and using them in a purposeful manner, in line with contextual aspects, such as the type of audience, nature of the subject and task at hand, as well as the learning outcomes in mind. Although, this study particularly focuses on the context of the COVID-19 pandemic, lessons learnt are arguably transferable to post-pandemic pedagogy and the blended-learning approach which has been stresstested under current circumstances.

\subsection{Limitations and future research}

This study has two main limitations. First, the paper reports findings that are based on qualitative data collected through eight in-depth interviews. The relatively small sample size in relation to the data collection can present some limitations. However, despite the limited sample size, this study includes more than one third of students, part of a particular module, who experienced on-campus as well as online tutorials. Furthermore, it draws on insights from both female and male students belonging to two different tutorial groups and programmes. Second, given the particular context of the module and the discipline it belongs to, the findings of this study may not be easily applied to other disciplines.

Limitations also provide opportunities for future research as a means of gaining greater understanding of students' perception of the use of technologies in the classroom. First, future research could expand on the sample size and extend this study to other programmes in the same discipline. Investigating this phenomenon with a larger sample size would help in obtaining a more nuanced understanding of the relationship between such aspects and students' learning styles/age and different technologies employed in the classroom. Second, the study could be replicated in a different context to observe potential variations related to, for example, the discipline and nature of the module. Third, a consistent understanding and interpretation of the term 'technology' have to be established and a more granular approach to the application and understanding of different tools is required. This study therefore calls for future research focusing on the categorisation of different technologies and platforms deployed in HE. Finally, and building on the previous recommendation, the differences between the technologies used in $\mathrm{HE}$ require further exploration. More specifically, there must be further investigation into the suitability of the various types of technology to the intended context and conditions.

\section{Acknowledgements}

We wish to express our thanks to the students of the Systems Management and Strategy Department, Business faculty who have participated in this study. Finally, we are very grateful for the feedback that we received at the SHIFT 2021 conference. 


\section{Reference list}

Advance HE. (2021) 'Gamification and Games-Based Learning.' Available at: https://www.advance-he.ac.uk/knowledge-hub/gamification-and-games-based-learning (Accessed: 24 February 2021).

Aksakal, N. (2015) 'Theoretical view to the approach of the edutainment.' Procedia-Social and Behavioral Sciences, 186, 1232-1239. Available at: https://www.sciencedirect.com/science/article/pii/S1877042815023411?via\%3Dihub (Accessed: 21 February 2021).

Bandura, A. and McClelland, D.C. (1977) Social learning theory (Volume 1). Englewood Cliffs, Hoboken, NJ: Prentice Hall. ISBN: 978-0-367-29712-1.

Bangert, A. (2004) 'The seven principles of good practice: a framework for evaluating onlineteaching.' Internet and Higher Education, 7(3), 217-32. Available at: https://www.sciencedirect.com/science/article/pii/S1096751604000405?via\%3Dihub (Accessed: 10 November 2020). BBC (2020) 'Coronavirus: Manchester universities move teaching online.' Available at: https://www.bbc.co.uk/news/uk-england-manchester54442380 (Accessed: 23 October 2020).

Bendassolli, P.F. (2013) 'Theory building in qualitative research: Reconsidering the problem of induction.' Forum Qualitative Sozialforschung/Forum: Qualitative Social Research 14(1), 1-20. Available at: https://www.qualitative-research.net/index.php/fqs/article/view/1851/3499 (Accessed: 30 January 2021).

Bernard, H.R. (1995) Research methods in anthropology. 2nd edition. Walnut Creek, CA: AltaMira Press. ISBN: 9780759101487

Bloom, B.S. (1956) Taxonomy of educational objectives. Volume 1: Cognitive domain. New York: McKay, 20-24. ISBN: 9780582280106

Bradshaw, T. (2021) 'Zoom fatigue brought into focus by Stanford study.' Available at: https://www.ft.com/content/55fe5592-7ad9-49d6-ba00-4c32860717df (Accessed: 24 February 2021).

Choi, S.B. and Lim, M.S. (2016) 'Effects of social and technology overload on psychological well-being in young South Korean adults: the mediatory role of social network service addiction.' Computers in Human Behavior, 61, 245-254. Available at: https://www.sciencedirect.com/science/article/pii/S0747563216301996?via\%3Dihub (Accessed: 12 February 2021).

de Klerk Wolters, F. (1989) 'A PATT study among 10 to 12-year-old students in the Netherlands.' Journal of Technology Education, 1(1), 1-8. Available at: https://vtechworks.lib.vt.edu/bitstream/handle/10919/8403/falco.pdf;jsessionid=E4C77E0925 5B2370C2BCF04E06ECFE0A?sequence $=1$ (Accessed: 4 February 2021).

Delpechitre, D., Black, H.G. and Farrish, J. (2019) 'The dark side of technology: examining the impact of technology overload on salespeople.' Journal of Business \& Industrial Marketing, 34( 2), 317-337. Available at: 
https://www.emerald.com/insight/content/doi/10.1108/JBIM-03-2017-0057/full/html (Accessed: 16 February 2021).

Dey, E.L., Burn, H.E. and Gerdes, D. (2009) 'Bringing the classroom to the web: Effects of using new technologies to capture and deliver lectures.' Research in Higher Education, 50(4), 377-393. Available at:

https://content.ebscohost.com/ContentServer.asp?EbscoContent=dGJyMMvl7ESeqLY4yOv sOLCmsEmep65Ss6e4S6\%2BWxWXS\&ContentCustomer=dGJyMPGrtky2prZQuePfgeyx9 Yvf5ucA\&T=P\&P=AN\&S=R\&D=ehh\&K=37043069 (Accessed: 6 January 2021).

Dolot, A. (2018) 'The characteristics of Generation Z.' E-mentor, 74(2), 44-50. Available at: https://www.researchgate.net/publication/328564137_The_characteristics_of_Generation_Z (Accessed: 15 February 2021).

Ebbert, D. and Dutke, S. (2020) 'Patterns in students' usage of lecture recordings: a cluster analysis of self-report data.' Research in Learning Technology, 28(0), 1-14. Available at: https://content.ebscohost.com/ContentServer.asp?EbscoContent=dGJyMMvl7ESeqLY4yOv sOLCmsEmep65Ss6q4TbSWxWXS\&ContentCustomer=dGJyMPGrtky2prZQuePfgeyx9Yvf5 ucA\&T=P\&P=AN\&S=R\&D=ehh\&K=144249426 (Accessed: 10 February 2021).

Eckleberry-Hunt, J., Lick, D. and Hunt, R. (2018) 'Is medical education ready for generation Z?' Journal of graduate medical education, 10(4), pp.378-381. Available at: https://meridian.allenpress.com/jgme/article/10/4/378/26/ls-Medical-Education-Ready-forGeneration-Z (Accessed: 10 February 2021).

Fosslien, L. and Duffy, M.W. (2020) 'How to combat zoom fatigue.' Harvard Business Review, 29. Available at: https://hbr.org/2020/04/how-to-combat-zoom-fatigue (Accessed: 22 January 2021).

Fry, H., Ketteridge, S. and Marshall, S. (2008) A handbook for teaching and learning in higher education: Enhancing academic practice. Location: Routledge. ISBN:

9781135724931

Fuglseth, A.M. and Sørebø, $\varnothing$. (2014) 'The effects of technostress within the context of employee use of ICT.' Computers in Human Behavior, 40, 161-170. Available at: https://www.sciencedirect.com/science/article/pii/S0747563214004142?via\%3Dihub (Accessed: 15 February 2021).

González-Gómez, D., Jeong, J.S., Rodríguez, D.A. and Cañada-Cañada, F. (2016) 'Performance and Perception in the Flipped Learning Model: An Initial Approach to Evaluate the Effectiveness of a New Teaching Methodology in a GeneralScience Classroom.' Journal of Science and Education Technology, 25(3), 450-459. Available at:

https://www.researchgate.net/publication/290982430_Performance_and_Perception_in_the_ Flipped_Learning_Model_An_Initial_Approach_to_Evaluate_the_Effectiveness_of_a_New_ Teaching_Methodology_in_a_General_Science_Classroom (Accessed: 15 February 2021).

Gorissen, P., Van Bruggen, J. and Jochems, W. (2012) 'Students and recorded lectures: survey on current use and demands for higher education.' Research in Learning Technology, 20. Available at:

https://content.ebscohost.com/ContentServer.asp?EbscoContent=dGJyMMvl7ESeqLY4yOv 
sOLCmsEmep69Sr6i4TLaWxWXS\&ContentCustomer=dGJyMPGrtky2prZQuePfgeyx9Yvf5u $c A \& T=P \& P=A N \& S=R \& D=e h h \& K=86228111$ (Accessed: 10 February 2021).

Harris, R.B. and Marett, K. (2009) 'An investigation of liking of computers, help received, and job outcomes for computer workers.' Journal of Organizational and End User Computing (JOEUC), 21(3), 60-79. Available at:

https://www.researchgate.net/publication/220068630_An_Investigation_of_Liking_of_Compu ters_Help_Received_and_Job_Outcomes_for_Computer_Workers (Accessed: 9 February 2012).

Harris, K.J., Harris, R.B., Carlson, J.R., and Carlson, D.S. (2015) 'Resource loss from technology overload and its impact on work-family conflict: Can leaders help?' Computers in Human Behavior, 50, 411-417. Available at:

https://www.sciencedirect.com/science/article/pii/S0747563215003106?via\%3Dihub (Accessed: 12 February 2021).

Hara, N. (2000) 'Student distress in a web-based distance education course.' Information, Communication \& Society, 3(4), 557-579. Available at: https://www.tandfonline.com/doi/pdf/10.1080/13691180010002297?needAccess=true (Accessed: 8 February 2021).

Hara, N. and Kling, R. (1999) 'Students' frustrations with a web-based distance education course.' First Monday, 4(12). Available at: http://www.firstmonday.org/article/view/710/620 (Accessed: 10 February 2021).

Henderson, M., Selwyn, N., Finger, G. and Aston, R. (2015) 'Students' everyday engagement with digital technology in university: exploring patterns of use and usefulness.' Journal of HE Policy and Management, 37(3), 308-319. Available at: https://content.ebscohost.com/ContentServer.asp?EbscoContent=dGJyMMvl7ESeqLY4yOv sOLCmsEmep69Ssqe4TLeWxWXS\&ContentCustomer=dGJyMPGrtky2prZQuePfgeyx9Yvf5 ucA\&T=P\&P=AN\&S=R\&D=buh\&K=102853874 (Accessed: 12 February 2021).

Hernandez-de-Menendez, M., Díaz, C.A.E. and Morales-Menendez, R. (2020) ‘Educational experiences with Generation Z.' International Journal on Interactive Design and Manufacturing (IJIDeM), 14(3), 847-859. Available at: https://www.researchgate.net/profile/Ruben-MoralesMenendez/publication/343356700_Educational_experiences_with_Generation_Z/links/5f4cf 91d92851c6cfd0efd2b/Educational-experiences-with-Generation-Z.pdf (Accessed: 9 February 2021).

Hughes, A. (2019) 'British Students Use One-quarter of Their Time Online for Studying, Poll Claims.' Available at: https://www.independent.co.uk/news/education/educationnews/university-students-internet-studying-uk-social-media-survey-a9111531.html (Accessed: 26 January 2021).

Jack, C and Higgins, S. (2018) 'What is educational technology and how is it being used tosupport teaching and learning in the early years?' International Journal of Early Years Education 27(3), 222-237. Available at:

https://www.researchgate.net/publication/326792715_What_is_educational_technology_and 
_how_is_it_being_used_to_support_teaching_and_learning_in_the_early_years (Accessed: 18 December 2020).

Johnson, D.W., Johnson, R.T. and Holubec, E.J. (1984) Cooperation in the Classroom. Edina, MN: Interaction Book Co. Publishing. ISBN: 9780939603121

Jung, I. (2003) 'Cost-effectiveness of online education.' Handbook of distance education, 717-726. Available at:

https://www.jstor.org/stable/44428629?seq=1\#metadata_info_tab_contents (Accessed: 28 January 2021).

Justice, C., Rice, J., Roy, D., Hudspith, B. and Jenkins, H. (2009) 'Inquiry-based learning in higher education: administrators' perspectives on integrating inquiry pedagogy into the curriculum.' Higher Education: The International Journal of Higher Education and Educational Planning, 58(841) Available at: https://link.springer.com/article/10.1007/s10734009-9228-7\#citeas (Accessed: 2 February 2021).

Karr-Wisniewski, P. and Lu, Y. (2010) 'When more is too much: Operationalizing technology overload and exploring its impact on knowledge worker productivity.' Computers in Human Behavior, 26(5), 1061-1072. Available at:

https://www.sciencedirect.com/science/article/pii/S0747563210000488 (Accessed: 10 February 2021).

King, K.P. (2002) 'Identifying success in online teacher education and professional development.' The Internet and Higher Education, 5(3), 231-246. Available at: https://www.sciencedirect.com/science/article/pii/S1096751602001045 (Accessed: 1 February 2021).

Kirkwood, A. and Price, L. (2005) 'Learners and learning in the twenty-first century: what do we know about students' attitudes towards and experiences of information and communication technologies that will help us design courses?' Studies in Higher Education, 30(3), 257-274. Available at:

https://www.researchgate.net/publication/42793205_Learners_and_learning_in_the_twentyfirst_century_What_do_we_know_about_students'_attitudes_towards_and_experiences_of_ information_and_communication_technologies_that_will_help_us_design_courses (Accessed: 8 February 2021).

Lam, P., McNaught, C., Lee, J. and Chan, M. (2014) 'Disciplinary difference in students' use of technology, experience in using eLearning strategies and perceptions towards eLearning.' Computers \& Education, 73, 111-120. Available at:

https://www.sciencedirect.com/science/article/pii/S0360131514000025 (Accessed: 29 January 2021).

Lee, J. (2020) 'A Neuropsychological Exploration of Zoom Fatigue. Available at: https://www.psychiatrictimes.com/view/psychological-exploration-zoom-fatigue (Accessed: 23 February 2021).

Lee, K., Courtney, M., McGlashan, A., Nevelsden, P. and Torso, M. (2020) 'Initial teacher education students' perceptions of technology and technology education in New Zealand.' 
International Journal of Technology and Design Education 30(3), 437-458. Available at: https://link.springer.com/article/10.1007/s10798-019-09516-6 (Accessed: 17 February 2021).

Lim, C.P. (2002) 'A theoretical framework for the study of ICT in schools: a proposal.' British Journal of Educational Technology, 33(4), 411-421. Available at: https://bera-

journals.onlinelibrary.wiley.com/doi/abs/10.1111/1467-8535.00278 (Accessed: 10 February 2021).

Mayhew, E. (2020) 'The impact of audience response platform Mentimeter on the student and staff learning experience.' Research in Learning Technology 28(0), 1-16. Available at: https://journal.alt.ac.uk/index.php/rlt/article/view/2397/2788 (Accessed: 4 February 2021).

McKie, A. (2020) 'Covid: Northumbria and Newcastle latest to move teaching online.'

Available at: https://www.timeshighereducation.com/news/covid-northumbria-and-newcastlelatest-move-teaching-online (Accessed: 23 October 2020).

Means, B., Toyama, Y., Murphy, R. and Baki, M. (2013) 'The effectiveness of online and blended learning: A meta-analysis of the empirical literature.' Teachers College Record, 115(3), 1-47. Available at:

https://learnonline.ecampusontario.ca/App_Content/Resource/docs/7b0981b7-dbd6-41d283b9-

67878a0ed052/The\%20effectiveness\%20of\%20online\%20and\%20blended\%20learning_\%2 0A\%20meta-analysis\%20of\%20the\%20empirical\%20literature.pdf (Accessed: 1 February 2021).

Mehta, K.J., Miletich, I. and Detyna, M. (2021) 'Content-specific differences in Padlet perception for collaborative learning amongst undergraduate students.' Research in Learning Technology, 29, 1-19. Available at:

https://journal.alt.ac.uk/index.php/rlt/article/view/2551 (Accessed: 10 February 2021).

Müller, F.A. and Wulf, T. (2020) 'Technology-supported management education: a systematic review of antecedents of learning effectiveness.' International Journal of Educational Technology in Higher Education, 17(1), 1-33. Available at:

https://educationaltechnologyjournal.springeropen.com/articles/10.1186/s41239-020-00226(Accessed: 3 February 2021).

Nordmann, E. and McGeorge, P. (2018) 'Lecture capture in higher education: time to learn from the learners.' PsyArXiv. Available at:

https://www.researchgate.net/publication/324943672_Lecture_capture_in_higher_education _time_to_learn_from_the_learners (Accessed: 15 February 2021).

Oblinger, D. and Oblinger, J. (2005) 'Is it age or IT? First steps toward understanding the net generation.' In: Oblinger, D. and Oblinger, J. (eds.), Educating the net generation, 12-31. EDUCAUSE. Available at: https://www.educause.edu/research-andpublications/books/educating-net-generation/it-age-or-it-first-steps-toward-understandingnet-generation (Accessed: 15 February 2021).

Papert, S.A. (1973) 'Uses of Technology to Enhance Education. MIT Artificial Intelligence.' Memo No. 298. Available at: https://dspace.mit.edu/handle/1721.1/6213 (Accessed: 23 October 2020). 
Parkin, M. (1998) Microeconomics (4th edition). Reading, MA: Addison-Wesley. ISBN:9780321522504

Partlow, K.M. and Gibbs, W.J. (2003) 'Indicators of constructivist principles in Internetbasedcourses.' Journal of Computing in Higher Education, 14(2), 68-97. Available at: https://link.springer.com/article/10.1007/BF02940939 (Accessed: 12th February 2021).

Patton, M.Q. (1990) Qualitative evaluation and research methods (2nd edition). NewburyPark, CA: SAGE Publications, Inc. ISBN: 9780803937796

Pellas, N. and Kazandis, I. (2015) 'On the value of Second Life for students' engagement in blended and online courses: A comparative study from the Higher Education in Greece.'

Education and Information Technologies, 20(3), 445-466. Available at: https://link.springer.com/article/10.1007/s10639-013-9294-4 (Accessed: 2 February 2021).

Poon, J. (2013) 'Blended learning: an institutional approach for enhancing students' learning experiences.' Journal of online learning and teaching, 9(2), 271-288. Available at: https://jolt.merlot.org/vol9no2/poon_0613.pdf (Accessed: 1 February 2021).

Reeves, L., Bolton, E., Bulpitt, M., Scott, A., Tomey, I., Gates, M. and Baldock, R.A. (2021) 'Use of augmented reality (AR) to aid bioscience education and enrich student experience.' Research in Learning Technology, 29(0), 1-15. Available at: https://journal.alt.ac.uk/index.php/rlt/article/view/2572 (Accessed: 8 February 2021).

Rovai, A.P. (2004) 'A constructivist approach to online college learning.' The internet and higher Education, 7(2), 79-93. Available at:

https://www.sciencedirect.com/science/article/pii/S1096751604000144 (Accessed: 2 February 2021).

Salaway, G., Caruso, J.B., and Nelson, M.R. (2007) The ECAR Study of Undergraduate Students and Information Technology, 2007. Boulder, CO: EDUCAUSE. Available at: https://er.educause.edu//media/files/articles/2008/8/ers0706w.pdf?la=en\&hash=B58D6709B30353FFF0E2A34FD10 4B941BA964F27 (Accessed: 28 January 2021).

Schmuck, R.A. (1997) Practical action research for change. Arlington Heights, IL: IRI/Skylight Training and Publishing. ISBN: 9781483362137

Shi, Y., Yang, H., MacLeod, J., Zhang, J. and Yang, H.H. (2020) 'College students' cognitive learning outcomes in technology-enabled active learning environments: A meta-analysis of the empirical literature.' Journal of Educational Computing Research, 58(4), 791-817. Available at: https://journals.sagepub.com/doi/abs/10.1177/0735633119881477 (Accessed: 11 February 2021).

Sjøberg, S. and Schreiner, C. (2010) The ROSE project: An overview and key findings (page 1). Oslo, Sweden: University of Oslo. Available at: https://roseproject.no/network/countries/norway/eng/nor-Sjoberg-Schreiner-overview2010.pdf (Accessed: 16 February 2021) 
Smyth, S., Houghton, C., Cooney, A. and Casey, D. (2012) 'Students' experiences of blended learning across a range of postgraduate programmes.' Nurse Education Today, 32(4), 464-468. Available at:

https://www.academia.edu/25843635/Students_experiences_of_blended_learning_across_a _range_of_postgraduate_programmes (Accessed: 16 February 2021).

Studentcrowd (2020) 'University Responses to Covid-19.' Available at:

https://www.studentcrowd.com/article/university-responses-to-covid-19 (Accessed: 23

October 2020).

Studentcrowd (2021) 'University Responses to Covid-19.' Available at:

https://www.studentcrowd.com/article/university-responses-to-covid-19 (Accessed: 26

February 2021).

Tarafdar, M., Tu, Q. and Ragu-Nathan, T.S. (2010) 'Impact of technostress on end-user satisfaction and performance.' Journal of Management Information Systems, 27(3), 303-334. Available at:

https://www.researchgate.net/publication/220591137_Impact_of_Technostress_on_EndUser_Satisfaction_and_Performance (Accessed: 4 February 2021).

Tolbert, E. (2015) 'The Impact of Computer-Aided Instruction on Student Achievement.' Gardner-Webb University, Boiling Springs. Available at: https://digitalcommons.gardnerwebb.edu/education etd/127/ (Accessed: 4 February 2021.

Toppin, I.N. (2011) 'Video lecture capture (VLC) system: A comparison of student versus faculty perceptions.' Education and Information Technologies, 16(4), 383-393. Available at: https://www.researchgate.net/publication/225515877_Video_lecture_capture_VLC_system_ A_comparison_of_student_versus_faculty_perceptions (Accessed: 26 January 2021).

Tugun, V., Bayanova, A.R., Erdyneeva, K.G., Mashkin, N.A., Sakhipova, Z.M. and Zasova, L.V. (2020) 'The Opinions of Technology Supported Education of University Students.' International Journal of Emerging Technologies in Learning, 15(23), 4-14. Available at: https://www.researchgate.net/publication/347616217_The_Opinions_of_Technology_Suppor ted_Education_of_University_Students (Accessed: 8 February 2021).

Vygotsky, L. (1978) Mind in society. Cambridge, MA: Harvard University Press. ISBN: 9780674576292

World Economic Forum (2020) 'COVID-19 has accelerated the digital transformation of higher education.' Available at: https://www.weforum.org/agenda/2020/07/covid-19-digitaltransformation-higher-education/ (Accessed: 23 October 2020).

Zhu, E. and Bergom, I. (2010) 'Lecture capture: A guide for effective use.' University of Michigan CRLT Occasional Papers (27). Available at:

https://www.researchgate.net/publication/239605672_Lecture_capture_A_guide_for_effectiv e_use (Accessed: 1 February 2021). 